\title{
Environmental Impact Assessment Draft Notification 2020, India: A Critique
}

\author{
Stellina JOLLY | ORCID: 0000-0002-4813-5700 \\ Senior Assistant Professor, Faculty of Legal Studies, South Asian University, \\ New Delhi, India \\ stellinajolly@sau.ac.in
}

Siddharth SINGH | ORCID: 0000-0003-3826-6616

Doctoral Student, Faculty of Legal Studies, South Asian University, New Delhi, India

singh.siddharth2014@gmail.com

\begin{abstract}
Environment Impact Assessment (EIA) is a systematic process to identify, predict, and evaluate the environmental effects of proposed actions and projects. Generally, an EIA is conducted before deciding to proceed with a specific project or activity. In India, the adoption of the Draft EIA Notification 2020 by the Ministry of Environment, Forest and Climate Change has triggered several debates over its problematic implications. The Draft EIA Notification normalizes ex post facto clearance, which allows construction or operation of the project without a prior environmental clearance. It has significantly curtailed the scope of public consultation and participation by the introduction of a large number of exemptions for projects. Further, it is silent over the project's transboundary impacts and exempts projects within $100 \mathrm{~km}$ of the border areas from public consultation. Thus, the Draft EIA Notification violates the environmental law principles provided under domestic and international laws by restricting adequate scrutiny of projects. The article critically evaluates the three significant dilutions that have threatened the effectiveness of the Draft EIA Notification including ex post facto clearance, public consultation, and the exemption granted to transboundary projects, and emphasizes its need for reconsideration before the publication of the final Notification.
\end{abstract}




\section{Keywords}

environment impact assessment - ex post facto clearance - India - precautionary principle - principle of non-regression - public consultation - sustainable development - transboundary impact

\section{Introduction}

On 23 March 2020, the Indian Ministry of Environment, Forest, and Climate Change (hereinafter 'the Ministry') issued Draft Environmental Impact Assessment Notification, 2020 (hereinafter the 'Draft EIA Notification'), which is intended to replace the existing EIA Notification, 2006. The stated intent of the Draft EIA Notification is to consolidate the incremental amendments to the 2006 notification, streamline and rationalize processes and implement decisions of various courts. The Draft EIA Notification was placed in the public domain with a period of 6 o days for public comments. ${ }^{1}$ In the face of fierce support for a longer period to facilitate a more comprehensive public consultation, the period of consultation was extended to 30 June 2020. ${ }^{2}$ However, in light of the countrywide lockdown due to Covid-19, this extension was considered insufficient by the Delhi High Court for an effective public consultation, and the period for receiving objections or suggestions was extended to 11 August 2020. ${ }^{3}$

The Draft EIA Notification has received robust criticism from environmentalists, civil societies, and the wider public. ${ }^{4}$ The fierce opposition to the Draft EIA Notification is seen in the fact that the Ministry received nearly 1.7 million

1 Ministry of Environment, Forest and Climate Change, Draft Environment Impact Assessment Notification, 2020, S.O. 1199(E) The Gazette of India: Extraordinary Part II Section 3(ii), 23 March 2020 <http://environmentclearance.nic.in/writereaddata/om/6998FGGHOI_ Gaztte_EIA2O2O_Comments.pdf >.

2 Ministry of Environment, Forest and Climate Change, s.o. 1429(E), 8 May $2020<$ http://moef .gov.in/wp-content/uploads/2020/05/EIA-2020_extn-of-period.pdf>.

3 Vikrant Singh Tongad v Union of India (MOE FCC), W.P.(C) 3747/2020 (Delhi HC 2020).

4 Stellina JOLLY, 'Draft EIA Notification 2020 Is Out of Sync With State Practices International Law' (The Wire, 31 July 2020) <https://thewire.in/environment/draft-environment-impact -assessment-notification-international-law>; Siddharth SINGH, 'The Problematic Story of Draft EIA Notification 2020' (Counter Currents, 2 August 2020) <https://countercurrents .org/2020/o8/the-problematic-story-of-draft-eia-notification-2020/>; Scroll STAFF, 'Over 6o former Bureaucrats urge Centre to withdraw Draft Environment Impact Assessment Policy' (Scroll, 12 July 2020) <https://scroll.in/latest/967280/over-6o-former-bureaucrats-urge -centre-to-withdraw-draft-environment-impact-assessment-policy>. 
comments by the deadline for public comments. ${ }^{5}$ This response is also the more striking given that the Draft EIA Notification was published only in English and Hindi and not in other vernacular languages. Publication of the Draft EIA only in English and Hindi has resulted in judicial scrutiny. The Delhi High Court ordered the translation of the Draft EIA Notification in 22 languages of the Eighth Schedule of the Constitution. ${ }^{6}$ Moreover, the Supreme Court of India dismissed the appeal filed by the Ministry against the order of the Delhi High Court. ${ }^{7}$

This article critically evaluates the Draft EIA Notification. It is argued that the Draft EIA Notification dilutes the very premise of EIA and emboldens violation of the core principles that are part of national and international environmental jurisprudence. The major dilutions include removing several activities from the purview of public consultation and EIA. Projects listed under Category 'B2' have been expressly exempted from the requirement of an EIA. ${ }^{8}$ The projects under this category include offshore and onshore oil, gas and shale exploration, hydroelectric projects up to $25 \mathrm{MW}$, irrigation projects between 2,000 and 10,000 hectares of command area, all inland waterway projects, expansion or widening of highways between $25 \mathrm{~km}$ and $100 \mathrm{~km}$ with defined parameters, and specified building construction and area development projects. ${ }^{9}$ These projects may require, for example, deforestation or the dredging of major rivers but do not need prior clearance for such activities. The Draft EIA Notification, controversially, allows projects to receive ex post facto clearances. ${ }^{10}$ The provision for ex post-facto approvals may be viewed as a blatant violation of the precautionary principle and defeats the very purpose of an EIA framework. The Draft EIA Notification states that cognizance of a violation will only be considered through a report by the government or the project developer or on a suo moto basis, completely excluding any role for public participation in decision-making. It is concluded that if enacted in its current form, the Draft EIA Notification will have severe consequences for

5 Jayashree NANDI, 'Centre gets 1.7 million suggestions on draft EIA' (Hindustan Times, 12 August 2020) <https://www.hindustantimes.com/india-news/centre-gets-1-7mn-sug gestions-on-draft-eia/story-sh7Mpbg6B 5 HwTynW8w5kDO.html>.

6 See Vikrant Singh Tongad (n 3); Simultaneously, in another petition filed before the Karnataka High Court, the court noted the absence of a reasonable period for filing objections and suggestions and ultimately restrained the Ministry from publishing the final EIA Notification till 7 September 2020. See United Conservation Movement Charitable and Welfare Trust $v$ Union of India, w.P. 8632/2O2O (Karnataka HC 2020).

$7 \quad$ Union of India v Vikrant Tongad, Special Leave to Appeal (C) No. 9169/2O2O (SC 202O).

8 See Draft EIA Notification (n 1) clause 13(11).

9 ibid schedule to the Draft EIA Notification.

$10 \quad$ ibid clause 22. 
environmental governance in India by negating the precautionary principle, diluting the due diligence process, and strengthening the discretionary power of the government while restraining public engagement in safeguarding the environment. In addition, Draft Notification is contrary to the newly emerging principle of non-regression.

The article is structured as follows. Sections 2 provides a contextual background by outlining the development of EIA in India. Section 3 focuses on the salient features of the Draft EIA Notification. Section 4 outlines three significant dilutions proposed, specifically, ex post facto clearance, restricted public consultation, and absence of focus on transboundary projects, and then evaluates their consequences for environmental protection.

Environment Impact Assessment in India: An Overview

Environment impact assessment was officially introduced in India through the 1994 EIA Notification adopted under Section 3 of the Environment (Protection) Act, 1986 read with Rule 5(3) of the Environment (Protection) Rules, 1986. ${ }^{11}$ The Notification followed the developments at the 1992 UN Earth Summit where the Rio Declaration adopted EIA as part of the catalogue of environmental protection principles. ${ }^{12}$ The Notification required 29 categories of projects listed in Schedule I to seek environment clearance (EC) before starting a new project or expansion or modernization activities..$^{13}$ The list includes, inter alia, thermal, hydro, and nuclear power projects, mining projects, oil and gas exploration projects, industries, infrastructure projects, and construction projects. ${ }^{14}$ The Ministry of Environment and Forests was designated as the agency to grant clearances, while the primary responsibility to prepare EIA was entrusted to the project proponent. ${ }^{15}$ The Notification stated that the application and reports submitted by the project proponents should be evaluated and assessed by the Impact Assessment Agency, and if deemed necessary, it may consult

\footnotetext{
11 Ministry of Environment and Forests, EIA Notification, 1994, S.O. 6o(E), 27 January 1994.

12 United Nations Conference on Environment and Development, Rio Declaration on Environment and Development, 3-14 June 1992, U.N. Doc. A/CONF.151/26, principle 17; see also Naveen THAYYIL, 'Public Participation in Environmental Clearances in India: Prospects for Democratic Decision-Making' (2014) 56 (4) Journal of Indian Law Institute $463,472-473$.

13 EIA Notification 1994 (n 11) Schedule I to the Notification.

14 ibid.

15 ibid clause 2; THAYYIL (n 12) 474-475.
} 
a Committee of Experts. ${ }^{16}$ The Notification provided that no construction work, preliminary or otherwise, relating to the setting up of the project may be undertaken until the environmental and/or site clearance is obtained. ${ }^{17}$ The clearance granted was valid for a period of five years for commencement of the construction or operation. ${ }^{18}$ In order to ensure effective monitoring, it was required that the project authorities submit a half-yearly report to the Impact Assessment Agency.

Since the 1994 Notification, 12 amendments were made in the EIA notification requirements up to 2006. The EIA Notification 2006 was to address the limitations in the $1994 \cdot{ }^{19}$

The amendment of 1997 introduced the process of environmental public hearing (EPH) ${ }^{20}$ The State Pollution Control Boards (SPCB S) were entrusted to conduct public hearings to elicit the concerns of the affected community and interested parties for the proposed project. ${ }^{21}$

The EIA Notification 2006 superseded the 1994 notification. Public consultation formalized through the 1997 amendment ${ }^{22}$ was incorporated as an essential component of EIA in 2006. ${ }^{23}$ The EIA Notification 2006 initiated the decentralization process to delegate the power to the State Governments. Projects in Schedule 1 were divided into two categories, Category 'A' and 'B'. Category 'A' requires clearance from Central Government, and Category 'B' requires clearance from State Government. However, the state government is required to determine if a Category ' $\mathrm{B}$ ' project falls under the ' $\mathrm{B} 1$ ' or ' $\mathrm{B} 2$ ' category. Category 'Br' projects require preparation of EIA reports, while the remaining projects are termed Category ' $\mathrm{B} 2$ ' projects. These do not require an EIA report.

Well-defined structures and stages of conducting the EIA were added to EIA Notification 2006. ${ }^{24}$ The first stage of screening determines whether a project requires an EIA report. The second stage (scoping) involves the determinants of terms of references covering all relevant environmental concerns for the

\footnotetext{
16 EIA Notification 1994 (n 11) clause 2(III)(a).

17 ibid clause $2(\mathrm{III})(\mathrm{c})$.

18 ibid.

19 Centre for Science and Environment 'EIA Legislation' <https://www.cseindia.org/ eia-legislation-402>.

$20 \quad$ Ministry of Environment and Forests, EIA Notification, s.o. 318(E), 10 April 1997.

21 Shibani GHOSH, 'Demystifying the Environmental Process in India' (2013) 6 National University Juridical Science Law Review 433.

22 EIA Notification 1997 (n 20).

23 Ministry of Environment and Forests, EIA Notification, 2006, s.o. 1533, 14 September 2006 $<$ http://parivesh.nic.in/writereaddata/ENV/EnvironmentalClearance-General/18.pdf>. ibid.
} 
preparation of the EIA. Public consultation and an appraisal of the EIA report that can result in either approval or rejection of the proposed project will follow the stages mentioned above. ${ }^{25}$ Similar to the 1994 Notification, the project management needed to submit half-yearly compliance reports. ${ }^{26}$

The last two decades of the functioning of EIA have revealed many flaws ranging from issues associated with accountability and transparency in the environmental clearance process to the quality of public participation. ${ }^{27} \mathrm{In}$ India, EIA has always remained in the form of a Ministerial Notification instead of fully-fledged legislation. This leaves significant scope for political discretion. The executive Notifications, being in the form of subordinate legislation, are bereft of any discussion in the Parliament. ${ }^{28}$ If, however, EIA were to be introduced as Rules under Section 26 of the Act, better scrutiny could be ensured, as the Rules have are required to be brought before the Parliament. ${ }^{29}$

Frequent amendments to the EIA Notifications are not updated in the main text of the EIA Notification 2006 but placed separately in a compendium on the official website, thus, creating a lack of clarity in the applicable law. ${ }^{30}$ Further, when the decentralization of the EIA process began with EIA Notification 2006, it created an imbalance between the regulating powers of the central government and the states. ${ }^{31}$ Ghosh highlights that the Orissa Government had accused the central government of bias wherein major infrastructure projects, which would have benefited the state, were denied sanction under Category ' $\mathrm{A} .{ }^{32} \mathrm{And}$, while stalling the projects in Orissa, sanctions were given to infrastructural projects in neighboring Andhra Pradesh. ${ }^{33}$ Similarly, in many reported cases, the decisions at the state level were influenced by local imperatives rather than real environmental concerns. However, it should be

25 Ruth KATTUMURI and Stefania LOVO, 'Decentralisation of Environmental Regulations in India' (2018) 53(43) Economic and Political Weekly 33.

26 EIA Notification 2006 ( $\mathrm{n} 23$ ) clause 10.

27 Nupur CHOWDHURY, 'Environmental Impact Assessment in India: Reviewing two decades of Jurisprudence' (2014) 5 IUCN Academy of Environmental Law e-Journal 28.

28 Stella JAMES and Nayana UDAYASHANKAR, 'From 2006 to 2020: The Ongoing Problems of the EIA' (Socio-Legal Review, 19 October 2020) <https://www.sociolegal review.com/post/from-20o6-to-202o-the-ongoing-problems-of-the-eia >.

29 ibid.

30 EIA Notification 2006 (Principal Rules), Compendium of Gazette Notifications, om s under EIA Notification 2006, subsequently amended notifications. <http://environment clearance.nic.in/writereaddata/EIA\%2oNotifications.pdf >.

31 GHOSH (n 21) 46o-463.

32 ibid.

33 ibid. 
noted that these incidents arose mostly from party politics rather than by reason of the Notification provisions.

Several Notifications have attempted to dilute the EIA process. ${ }^{34}$ While the Ministry has consistently weakened the process of EIA on one side, the judiciary has tried to protect and preserve the rigor of the EIA on the other side. For example, in S.P. Muthuraman v. Union of India, the National Green Tribunal (NGT) quashed the Office Memorandum (OM) that asked the project proponent to submit a written commitment to non-repetitions of their violations and required the state government to initiate credible action against violations, invoking its power under the EPA 1986. Once these steps are taken, the project proponent can become entitled to obtain the Environmental Clearance. The Tribunal noted that the authorities had taken proceedings against some proponents, while no action had been taken against the others. Moreover, they had not been subjected to any penalties for the violations. Thus, the two oms allow project proponents to violate EIA laws instead of holding them accountable for their wrongs. ${ }^{35}$ Similarly, the Delhi High Court stayed Ministry Notifications for granting an exemption to the project proponents from obtaining Environment Clearance for 50,ooo sq. meters built-up area in cases of building projects and 150,00o sq. meters for industrial sheds, educational institutions, and hospitals. ${ }^{36}$

Judicial statements have further attempted to streamline the environmental clearance by insisting on reasoned decisions, ${ }^{37}$ disclosure of facts, ${ }^{38}$ need for transparency, and legal rationality. ${ }^{39}$ In Lafarge Umiam Mining Private Limitedv.

34 Some of the Ministry Notifications that have weakened the principles of EIA are as follows:

"(i) MoEF, EIA Notification, s.o. 1119(E) (13 December 200o) exempted defense-related road construction projects in border areas from the provisions of the 1994 Notification; (ii) MoEF, EIA Notification, s.o. 632(E) (13 June 2002) exempted pipeline projects from obtaining EIA report under 1994; (iii) MoEF\&CC, EIA Notification, so. 2559(E) (22 August 2013) <http://ismenvis.nic.in/Database/Notification22082013_3734.aspx>, removed the expansion of certain categories of national and state highways from scoping; (iv) MoEF\&CC, EIA Notification, s.o. 996(E) (10 April 2015) removed the requirement of scoping for certain highway projects in border States."

35 S.P. Muthuraman v Union of India, Original Application No. 37/2015 (NGT 2015).

36 Social Action for Forest and Environment v Union of India, W.P.(C) 12517/2018 \& 12570 of 2018 (Delhi HC 2018) (pending); see Shashikant Vithal Kamble v Union of India, Original Application No. 1017/2018 (NGT 2018); Society for Protection of Environment and Biodiversity $v$ Union of India, Original Application No. 677/2016 (NGT 2017).

37 Utkarsh Mandal v Union of India, W.P.(C) 9340/2009 (Delhi HC 2009).

38 T. Mohana Rao \& Ors. v MOEF and Ors., Appeal No. 23/2011 (NGT 2012).

39 See for a critical look at the role of the judiciary in environment matters, see Stellina JOLLY and Zen MAKUCH, 'Procedural and substantive innovations propounded by the 
Union of India ${ }^{40}$ the Supreme Court of India recommended the establishment of a national environmental regulator to reform the existing environmental clearance mechanism and monitoring process under EIA. ${ }^{41}$ However, the government is critical of establishing such a regulator, and no steps have been taken to implement the recommendation of the Supreme Court. ${ }^{42}$ The Draft EIA Notification is a continuation of these developments and should be seen against the broader background of a series of dilutions and facilitating the ease of doing business by the successive governments.

The Draft EIA Notification 2020 has incorporated many of the provisions already included in several Ministry notifications and amendments since 2006. ${ }^{43}$ However, it makes some core changes in the substance and process of EIA in comparison to the EIA Notification 2006. The Draft EIA Notification has introduced a list of definitions to clarify the meaning and operation of the EIA framework. ${ }^{44}$ It specifies three categories of projects as ' $\mathrm{A}$ ', 'B1', and 'B2' and eliminated the requirement of classifying projects on a case-to-case basis for Category 'B'. Under the EIA Notification 2006, State Environment Appraisal Committees (SEAC) had to classify whether the project fell under 'B1' or 'B2' depending on the spatial extent of potential impacts and potential impacts on human health and natural and man-made resources. ${ }^{45}$

Compared to the four stages of EIA prescribed under the EIA Notification 2006, the Draft EIA Notification proposes a 6-stage process: including Scoping,

Indian judiciary in balancing protection of environment and development: a legal analysis' in Christina VOIGT and Zen MAKUCH (eds), Courts and the Environment (Edward Elgar 2018) 142-169.

$40 \quad$ Lafarge Umiam Mining Private Limited v Union of India \& Ors. ((2O11) 7 SCC 338).

41 Shashwat PANDEY, 'Does India Require Environment Super-regulator: A Critical Analysis of the Extant and Innovate' (2015) 11 Procedia Earth and Planetary Science 247.

42 Sanjay SHARMA and Ajay Kumar SINGH, 'Environmental Regulatory Authorities in India: An Analysis' (2018) 64(4) Indian Journal of Public Administration 627.

43 Manju MENON \& Kanchi KOHLI, 'EIA Legitimised Environmental Destruction. Now, Govt "Renovates" it for the West' (The Wire, 24 June 2020) <https://science.thewire.in/ environment/eia-202O-environmental-degradation-draft/>. See Kanchi KOHLI \& Manju MENON, 'Analyzing the Draft Environmental Impact Assessment (EIA) Notification 2020' (Centre for Policy Research, 28 May 2020) <https://www.cprindia.org/news/ analysing-draft-environmental-impact-assessment-eia-notification-2020>.

44 Draft EIA Notification ( $\left.n_{1}\right)$ clause 3.

45 EIA Notification 2006 (n 23). 
Preparation of Draft EIA Notification, Public Consultation, Final EIA, Appraisal and Grant or Rejection of Environmental clearance or environmental permission. The screening stage, which was part of the EIA Notification 2006, is absent under the Draft EIA Notification. It was under this stage that the SEAC could determine whether projects under category 'B' required environmental impact assessments. The Draft EIA Notification explicitly lists the projects into Category 'B1', which requires EIA, and Category 'B2', which do not require EIA but will require environmental permission. Environmental permission (EP $)^{46}$ has been introduced as a new type of approval in the Draft EIA Notification along with the existing mode of prior environmental clearance. ${ }^{47}$ There are apprehensions that this would seriously affect the environment, since these will be carried out merely based on EP without a detailed assessment. ${ }^{48}$ The Draft EIA Notification does not elaborate on how an EP will be different from an EC.

There are some positives to the Draft EIA Notification. First, it proposes the formation of a Technical Expert Committee to undertake categorization or recategorization of projects on scientific principles. ${ }^{49}$ This is a modification from the current position of the categorization of the projects which is undertaken on the basis of the 'spatial extent of potential impacts on human health and natural and man-made resources. ${ }^{50}$ Second, it reduces the period for the final decision concerning grant or rejection of EC or EP to ninety days of submitting the final application and supporting documents from one hundred and five days. ${ }^{51}$ Third, it incorporates the provision for an appeal against the grant of EC or EP to the National Green Tribunal within thirty days of the decision of the regulating authority. ${ }^{52}$ This should be viewed as a positive step against the possible arbitrary decision-making process of the regulatory authority.

On the flip side, the Draft EIA Notification promotes many exemptions and dilution of the EIA process. ${ }^{53}$ As many as 40 projects ranging from clay and sand extraction, coal and non-coal mineral extraction, minor irrigation etc. are

46 Draft EIA Notification (n 1) clause $3(41)$.

47 ibid clause 4 .

48 ibid clause 5(6) and $10(3)$. See G ANANTHAKRISHNAN, 'The Hindu Explains: What are the key changes in the Environment Impact Assessment Notification 2020?' (The Hindu, 2 August 2020) <https://www.thehindu.com/sci-tech/energy-and-environment/ the-hindu-explains-what-are-the-key-changes-in-the-environment-impact-assessment -notification-2020/article32249807.ece>.

49 Draft EIA Notification ( $\mathrm{n}_{1}$ ) clause 9.

$50 \quad$ EIA Notification 2006 (n 23) clause 4.

51 Draft EIA Notification (n 1$)$ clause 17.

52 ibid clause 25 .

53 See ibid clauses $5(6), 5(7), 12(1), 14(2), 19(1)(\mathrm{I}), 20(4)$ and 26. 
exempted from prior EC or prior EP. 'B2' projects and several other projects dealing with projects located beyond the 12 Nautical Mile limit, and modernization of irrigation etc. are exempted from public consultation. Project proponents are only required to submit a compliance report once a year, contrasted with the half-yearly requirement in the EIA Notification 2006. The Draft EIA Notification provides power to the central government to constitute state-level and district level regulatory authorities and expert committees inconsistent with the decentralization scheme and tilting the balance in favor of the centre. ${ }^{54}$ Further, Clause 5(7) of the Draft EIA Notification states that no information relating to the projects involving strategic considerations shall be placed in the public domain. ${ }^{55}$

\section{Dilution of Environmental Standards}

This section will outline some of the dilutions of environmental standards in the Draft EIA Notification. It will be seen that its contents are problematic, as they violate the fundamental rights guaranteed in the Constitution and deviate from India's international legal commitments undertaken at several environmental forums.

It could also be argued that the dilution of the EIA norms detailed here are contrary to the newly emerging principle of non-regression, that has now been recognized in various international fora ${ }^{56}$ well as by at least one national legislature. ${ }^{57}$

In this section, three particularly problematic areas of the Draft E IA Notification 2020 are examined: ex post facto clearance, reduced public consultation, and exempting projects near border areas from public consultation.

54 MENON \& KOHLI (n 43).

55 Draft EIA Notification (n 1 ) clause $5(7)$.

56 Michel PRIEUR and Gaëll MAINGUY 'Non-regression in environmental law' SAPIENS 5.2 2012 <https://journals.openedition.org/sapiens/1405>; the IUCN World Declaration on the Environmental Rule of Law, states in Principle 12 'Non-regression: States, sub-national entities, and regional integration organisations shall not allow or pursue actions that have the net effect of diminishing the legal protection of the environment or of access to environmental justice' <https://www.iucn.org/commissions/ world-commission-environmental-law/wcel-resources/wcel-important-documentation/ environmental-rule-law >.

See Article L. 110-1 II $9^{\circ}$ of the Environmental Code of France, introduced in 2016. 


\subsection{Ex Post Facto Clearance}

EIA is premised on conducting a prior clearance mechanism for understanding the environmental and social impact of a proposed project. It advances the objective of the precautionary principle accepted as part and parcel of India's environmental jurisprudence. ${ }^{58}$ The precautionary principle provides for measures to avert risks of severe or irreversible harm to the environment or human health in the face of scientific uncertainty. ${ }^{59}$ Successive judicial decisions have recognized the precautionary principle as an essential part of the Indian domestic law framework. In Vellore Citizens Welfare Forum v. Union of India $^{60}$ the court interpreted the precautionary principle to include the following components;

- State government and the statutory authorities must anticipate, prevent, and attack the causes of environmental degradation.

- Where there are threats of serious and irreversible damage, lack of scientific certainty should not be used as the reason for postponing measures to prevent environmental depredation.

- The 'onus of proof' is on the actor or the developer/industrial to show that their action is environmentally benign. ${ }^{61}$

Precautionary measures are initiated based on scientific information and analysis of possible risks to human health and the environment, even if those risks are only tentative. ${ }^{62}$ In this process, EIA provides the foundational tool for decision making by providing information about potential risks and harm. The grant of ex post facto environmental clearances does not sit comfortably with this. ${ }^{63}$ Environmental harm can be irreparable and it is better to avoid any damage to the environment rather than to try remedy it. Prevention is, after all, better than cure. The very premise of EIA is to understand the environmental and social consequences of a project before the project is undertaken. Under the legal framework, there are already categories of projects exempted from EIA's requirements. Thus, going beyond those categories and allowing projects

58 Lavanya RAJAMANI, 'The Precautionary Principle' in Shibani GHOSH (ed), Indian Environmental Law: Key Concepts and Principles (Orient BlackSwan 2019); see M.C. Mehta $v$ Union of India, W.P.(C) No. 4677/1985 (SC 2004); Piedade Filomena Gonsalves $v$ State of Goa \& Ors., 3 SCC 445 (SC 2004).

59 Gitanjali N GILL, 'Precautionary Principle, its Interpretation and Application by the Indian Judiciary: "When I use a Word it Means Just What I Choose it to Mean-neither More or Less" Humpty Dumpty' (2019) 21(4) Environmental Law Review 292.

6o Vellore Citizens Welfare Forum v Union of India., 19965 SCC 647 (SC 1996).

61 ibid.

62 RAJAMANI (n 58$)$ 196-197.

63 Alembic Pharmaceuticals Ltd v Rohit Prajapati \& Ors., Civil Appeal No. 1526 of 2016 (sC 2020). 
to be initiated without EC defeats the original intent of protecting the environment through EIA. It should also be understood that as part of the EIA, analysis is undertaken regarding the suitability of the location or the possibility of an alternative site. In the case of ex post facto project clearance, the option of exploring a better alternative is lost, as the project has already been commenced. A project proponent is, of course, taking on a significant financial risk by commencing development without EC. They face the risk of closure or any other penalty if EC is refused. That voluntary assumption of risk aside, from an environmental perspective, if the EC were rejected, the damage done may be irreparable in many cases. Further, it has generally been noted that in most of the cases where the project proponents have applied for ex post facto clearance, the EC has been given without insisting on a stricter analysis. Thus, there is a real fear of diluting the spirit of EIA.

The fear of dilution is exacerbated by an analysis of the many cases where the EC s have been given after the project's commencement. For instance, it was found that the Indian Institute of Technology, Madras (IIT-M), between 2002 and 2013 , increased the built-up area on campus by $5^{2}$ acres, eating into nearly eight percent of the city's forest cover in an ecologically sensitive area without obtaining the relevant environmental clearance under the $2006 \mathrm{EIA}$ Notification. ${ }^{64}$ The State Environmental Impact Authority asked the IIT-M to tender an apology, and the same was accepted by the authority, which went ahead to grant the ex post facto clearance. ${ }^{65}$

Clause 22 of the Draft EIA Notification incorporates ex post facto clearance provisions. It provides that a committee will appraise the lack of environmental clearance and its consequences for an already initiated project. The Committee will assess whether the construction or expansion of the project complies with environmental norms. If answered in the negative, the project's closure will be recommended. Alternatively, if answered in the positive, the project will be granted clearance. ${ }^{6}$ In essence, the Draft EIA Notification directs the closure of the project only when the project is not sustainable within environmental norms. Thus, it sends a message to the project proponents that obtaining an EC is not mandatory and that the default may be condoned retrospectively. The fact that it encourages the proponent to 'pollute and (hopefully) pay' without obtaining the prior EC is troubling. It is important to note that under the 1994

64 Nityanand JAYARAMAN, "Ex-post facto prior environmental clearances": How a nonsensical phrase was used to flout the law' (Scroll, 11 July 2015) <https://scroll.in/ article/740252/ex-post-facto-prior-environmental-clearances-how-a-nonsensical-phrase -was-used-to-flout-the-law >.

65 ibid.

66 Draft EIA Notification (n 1) clause 22(2) and (3). 
EIA Notification and the 2006 EIA Notification, there was no provision for ex post facto clearance. Thus, the Draft EIA Notification represents a significant departure from existing practice.

The incorporation of the ex post facto clearances goes against basic tenets of preventive action highlighted in international law and Indian law. ${ }^{67}$ The Indian judiciary has curtailed the practice of ex post facto clearance in the domestic arena. In Kerala State Coastal Zone Management Authority v. State of Kerala Maradu Municipality, the Supreme Court, while negating the ex post facto clearance, ordered the demolition of buildings constructed without valid permissions and in violation of the Coastal Regulation Zone Notification. ${ }^{68}$ The Supreme Court pointed out that a project's commencement without obtaining environmental clearance is a violation of local people's fundamental right to life guaranteed under Article 21 of the Indian Constitution. ${ }^{69}$ At the international level, in the Pulp Mills case, the International Court of Justice not only specifically stressed the need to have an EIA conducted prior to implementing a project, but it also emphasized the need for continuous monitoring of the project concerning its effects on the environment. ${ }^{70}$

Notably, the Ministry had adopted a Notification issued on 14 March 2017 that allowed projects to seek an environmental clearance after their operations, construction, or modernization in violation of environment impact assessment conditions. ${ }^{71}$ It provided a six-month window to apply for ex post facto clearances to the project proponents. ${ }^{72}$ This provision received significant backlash as it encourages the violation of the precautionary principle. However, the Madras High Court had upheld the validity of the 2017 Notification based on the two submissions made by the Advocate Solicitor General that (a) public

67 Vigilance and prevention on account of irreparable environmental damage were highlighted in Gabčíkovo-Nagymaros Project (Hungary/Slovakia), Judgment, 1997 I.C.J. 7, 78, para 140 ( 25 September); Preventive action before environmental damage was highlighted in Certain Activities Carried out by Nicaragua in the Border Area (Costa Rica v Nicaragua) and Construction of a Road in Costa Rica along the San Juan River (Nicaragua $v$ Costa Rica), Judgment, 2015 I.C.J. 665, 793, para 14 (16 December), see Separate Opinion of Judge BHANDARI.

68 Kerala State Coastal Zone Management Authority v State of Kerala Maradu Municipality, Civil Appeal No. 4784-4785 of 2019 (SC 2019).

69 Association for Environment Protection v State of Kerala, Civil Appeal No. 4941 of 2013 (sc 2013).

70 Case Concerning Pulp Mills on the River Uruguay (Argentina v Uruguay), Judgment, 2010 ICJ 14, 83-84, para. 205 (20 April).

71 Ministry of Environment, Forest and Climate Change, EIA Notification, s.o. 804(E) (14 March 2017), <http://moef.govin/wp-content/uploads/2018/o7/101-SO804E-14032017 $. p d f>$.

72 ibid. 
hearing will be included during the EIA process of these projects, and (b) it will be a one-time measure. ${ }^{73}$ The Draft EIA Notification's institutionalization of a one-time exception as a general norm goes against the very concept and purpose of EIA and cannot be legally justified.

However, the ex post facto provision is not expected to be sustained in the face of judicial scrutiny. In Alembic Pharmaceuticals Ltd $v$. Rohit Prajapati \& Others, the Supreme Court of India has held that the concept of ex post facto EC is in derogation of the fundamental principles of environmental jurisprudence. ${ }^{74}$ The Supreme Court in Common Cause v. Union of India held that the grant of an ex post facto EC is detrimental to the environment and could lead to irreparable degradation of the environment. ${ }^{75}$ In the context of these clear judicial precedents, it may be considered unusual that the Ministry wished to retain the provision on ex post facto clearance in the Draft EIA Notification.

It may be concluded that projects initiated and operationalized without EC constitute a threat to the environment and local communities. The consequences of such a process were seen in the LG polymer gas leak incident at Visakhapatnam on 7 May 2020. The styrene gas leak incident took 11 lives, caused injury to more than 100 people, and destroyed nearby flora and fauna. ${ }^{76}$ The entity responsible had been operating without the necessary EC for years. Similarly, on 27 May, 2020, a gas well operated by Oil India Limited in Baghjan, Assam, had a blowout of gas and oil that caught fire. This resulted in fatalities, displacement of the local population and had an irreversible effect on the ecological features of the surrounding areas. Notably, it had received an EC on 11 May 2020, just over two weeks prior to the accident, to explore and extract gas without going through a public hearing process. ${ }^{77}$ This instance is not to

73 Puducherry Environment Protection Association v Union of India, w.P. No. 11189 of 2017 (Madras HC 2017).

74 Alembic Pharmaceuticals (n 63).

75 Common Cause v. Union of India, w.P. (C) No. 114 of 2014, para 124 (SC 2017); see M.C. Mehta (n ${ }_{58) \text {. }}$

76 Amit KUMAR, 'Vizag Gas Leak: Why the NGT Should Have Applied Absolute, Not Strict, Liability' (The Wire, 13 May 2020) <https://thewire.in/rights/vizag-gas-leak-ngt -strict-absolute-liability>.

77 Jay MAZOOMDAAR, 'Days Before Assam Fire, oIL Cleared Curbs to Get nod for Project inside National Park' (The Indian Express, 6 July 2020) <https://indianexpress.com/ article/north-east-india/days-before-assam-fire-oil-cleared-curbs-to-get-nod-for-project -inside-national-park-6491917/>; Rishika PARDIKAR, 'Three Oil Exploration Proposals up for Consideration in Assam even as Baghjan Smoulders' (Down To Earth, 1 July 2020) $<$ https://www.downtoearth.org.in/news/environment/three-oil-exploration-proposals -up-for-consideration-in-assam-even-as-baghjan-smoulders-72068>. 
argue that there is a direct relationship between disaster and lack of public consultation. However, the idea behind having a public consultation in the EIA is not just to encourage participatory democracy but also to regulate the topdown notion of governance. In many cases, public concerns and views become relevant in setting up adequate safety features and alternatives to the project. Projects that proceed without appropriate clearances could be disastrous for the local environment. They are unable to provide adequate safeguards and prevent communities affected by the project to voice their concerns.

\subsection{Public Consultation}

Public consultation and associated procedural human rights in the form of access to information and access to justice have been strengthened through the Rio Declaration and other multilateral environmental agreements. ${ }^{78}$ The articulation of public participation in these international instruments signifies the legal avenues of public awareness and informed decision-making in environmental matters. Under the Draft EIA Notification, public consultation enables the locally affected population and those with a plausible stake in the proposed project's environmental impact to raise their concerns. ${ }^{79}$ It deserves attention because it may be asserted that broader participation creates more information and alternatives for the decision-makers, thus enhancing the overall quality of the environmental impact analysis process. ${ }^{80}$

${ }_{7} 8$ Rio Declaration (n 12) principle 10; United Nations Economic Commission for Europe, Convention on Access to Information, Public Participation in Decision-Making and Access to Justice in Environmental Matters, 25 June 1998, 2161 Treaty Series 447; United Nations Economic Commission for Europe, Convention on Environmental Impact Assessment in a Transboundary Context, 25 February 1991, 1989 Treaty Series 309, article 3.8. Whilst India is not a party to the 1991 Espoo Convention, it should acknowledge the minimum standards for conducting EIA in the domestic context, as prescribed by this Convention. UNEP Principle 7 emphasizes providing opportunities to the members of the public to comment on EIAs. See United Nations Environmental Programme, Goals and Principles of Environmental Impact Assessment, UN Doc. UNEP/GC/14/25, 14th Session (1987), endorsed by UNGA Res. 42/184; Multilateral financing institutions adhere to the incorporation of public consultation and participation in EIAs with respect to their lending projects. Public participation is adopted as a part of EIA systems in both developed and developing countries in some form or another. Countries in Latin America and Central and Eastern European (CEE) have the incorporated participatory approaches while modernizing their environmental policy and regulatory systems.

79 Draft EIA Notification ( $\mathrm{n}_{1}$ ) clause $14(1)$ (a) \& (b). It is not clear who determines (and how) whether or not a person has a 'plausible stake' in the environmental aspects of the project or activity.

8o THAYYIL (n 12); see also Anne N GLUCKER, Peter PJ DRIESSEN, Arend KOLHOFF and Hens AC RUNHAAR, 'Public participation in environmental impact assessment: why, who and how?' (2013) 43 Environmental Impact Assessment Review 104. For an 
Public consultation has been an 'Achilles' heel' in Indian environmental governance. The Draft EIA Notification continues with the dilution of public consultation and brings in an additional category of exemptions to that required under the 2006 EIA Notification. The 2006 EIA Notification had prescribed that all Category ' $\mathrm{A}$ ' and Category 'B1' projects undertake public consultation. The Draft EIA Notification provides an exemption for Category 'A' and 'B1' expansion proposals or modernization with a capacity increase of less than 50 percent from public consultation. The project proponents can divide the expansion or modernization into phases and show it as less than 5o percent and avoid public scrutiny. The Draft EIA Notification retains the much-criticized exemption for building, construction, and area development projects from public consultation without providing any justification. ${ }^{81}$ There have been many cases where the residents have opposed construction activities in their vicinity. The exemption granted to buildings and construction deprives the public of any say in these activities. Similarly, exemption from public consultation to the modernization of irrigation projects has been retained. ${ }^{82}$

All projects and activities falling under Category 'B2' will be exempted from public consultation. These include the mining of minor minerals in less than or equal to 5 hectares of the mining lease area, exploration of offshore and onshore oil and gas, and river valley projects up to 25 megawatts hydroelectric power generation. ${ }^{83}$ As with the EIA 2006 Notification, it exempts all projects concerning national defense and security or involving other strategic considerations determined by the Central Government from public consultation and additionally prohibits any related information to be placed in the public domain. The absolute discretionary authority of the government to categorize projects as strategic and exempt them from public hearings, thus excusing it from placing it on the public domain is against the basic tenets of

effective EIA, public participation must commence from the early stages of project design and should be allowed even beyond the authorization, see Shahin ALAM, 'Public Participation in the Enforcement of Environmental Laws: Issues and Challenges in the light of the Legal and Regulatory Framework with Special reference to EIAs in Malaysia' (2014) 3(1) Bangladesh Research Foundation Journal 87.

81 Draft EIA Notification (n 1) clause 14(2)(c) read with schedule to the Draft EIA.

82 ibid clause $14(2)$ and $14(2)(a)$.

83 ibid clause 14(2) read with schedule. According to Section $3(\mathrm{e})$ of the Mines and Minerals (Development and Regulation) Act, 1957 "Minor Minerals" means building stones, gravel, ordinary clay, ordinary sand other than sand used for prescribed purposes and any other mineral which the Central Government may, by notification in the Official Gazette, declare to be a minor mineral. 
environmental procedural rights recognized under several multilateral instruments to which India is a party. ${ }^{84}$

The exemption of public consultation from the Category 'B2' projects is problematic, since the list includes numerous projects capable of causing severe impacts on the ecology and local communities. For instance, the Government of India's ambitious Char Dham initiative to connect the four pilgrimage sites requires the expansion of $900 \mathrm{~km}$ of highways in an eco-sensitive and fragile Himalayan mountain region. ${ }^{85}$ The Ministry of Road Transport and Highways has divided the 9oo-kilometer highway into 53 segments where all of them are shorter than $100 \mathrm{~km}$ and thus avails an exemption from EIA Notification of 2013. ${ }^{86}$ The Draft EIA Notification exempts the expansion or widening of existing National Highways by the length between $25 \mathrm{~km}$ and $100 \mathrm{~km}$ involving widening or right of way more than $70 \mathrm{~m}$ on existing alignments or re-alignments or by-passes from public consultation. ${ }^{87}$ Notably, despite their exemption, massive constructions involving slope cutting, falling of trees, and soil displacement in a fragile and threatened region can intensify disasters and threaten the lives and ecosystems of the area.

The Draft EIA Notification has reduced the period of public hearings from 30 to 20 days. ${ }^{88}$ In the light of the socio-economic circumstances of the vulnerable population affected by these projects, restricting the consultation period to 20 days is unjustifiable and would practically exclude many groups from the consultation. The current period of 30 days has already been under scrutiny by environmentalists and regarded as unsatisfactory. ${ }^{89}$ The important threshold is whether there has been a reasonable time for consultation. By way of comparison, the European Union Directive on the assessment of the effects of certain public and private projects on the environment requires provision of a time

84 Rio Declaration (n 12) principle 10; Paris Agreement to the United Nations Framework Convention on Climate Change, 12 December 2015, UnTS 52, article 12.

85 The CharDham is a set of four pilgrimage sites located in the four corners of India, namely, Badrinath, Dwaraka, Puri and Rameswaram. See Kabir AGARWAL, 'Char Dham Highway Case: SC Overrules NGt, Sends Matter Back to Original Bench' (The Wire, 27 August 2018) $<$ https://thewire.in/environment/char-dham-highway-case-sc-overrules-ngt>.

86 Ministry of Environment and Forests, EIA Notification, s.o. 2559(E) (22 August 2013), http://ismenvis.nic.in/Database/Notification22082013_3734.aspx; AGARWAL (n 85).

87 Draft EIA Notification $\left(\mathrm{n}_{1}\right)$ item 38 of the schedule.

88 ibid appendix-I, item 3 and 7 .

89 MP Ram MOHAN and Himanshu PABREJA, 'Public Hearings in Environmental Clearance Process: Revies of Judicial intervention' (2016) 51(50) Economic \& Political Weekly 68, 70-71; see Padmaparna GHOSH, 'Public hearing: a mere formality?' (Mint, 11 February 2008) <https://www.livemint.com/Home-Page/MD6bEVXOwDbJEGULhJM sVK/Public-hearing-a-mere-formality.html >. 
period for the public concerned to prepare and participate in environmental decision making. ${ }^{90}$ Taking into account the socio-economic profile of the generally affected population, physical and geographical access, and ignorance of procedural access rights, a period of 20 days cannot be considered reasonable.

The proposed reduction in the public consultation period also departs from the case law that has evolved in the country. ${ }^{91}$ Public participation and its contours had been expanded through the rights jurisprudence under the expanded notion of the right to life under Article 21 of the Indian Constitution. In the case of the Research Foundation for Science Technology and Natural Resources Policy $v$. Union of India, the court dealt with dumping hazardous wastes, its generation, and severe and irreversible damage as a result thereof to the environment. In the context of waste disposal and Ec, the court held that the right to life under Article 21 includes the right to information and community participation to protect the environment and human health. ${ }^{92}$ In Orissa Mining Corporation Ltd $v M O E F$, popularly known as the Vedanta judgment, the Supreme Court of India explicitly recognized the significance of the voice of tribal communities whose right to life and livelihood depends upon forests and the need for granting them a permanent stake in conservation regime. ${ }^{93}$ The case involved the denial of EC to construct an alumina refinery in the Niyamgiri Hills, Orissa. The Supreme Court held that the Gram Sabha has authority to determine whether the proposed project would affect individual or community rights and that this is a precondition before the mining process in Niyamgiri Hills can proceed. ${ }^{94}$ The case is significant in elevating the concept of public consultation to that of public consent in the context of Scheduled Tribes. Similarly, the Delhi High Court in Samarth Trust v. Union

90 Directive 2011/92/EU on the assessment of the effects of certain public and private projects on the environment (codification) [2012] of L 26/1.

91 Centre for Social Justice v Union of India \& Ors., AIR 2001 Guj 71 (Gujrat HC 2000); Utkarsh Mandal (n 37).

92 Research Foundation for Science Technology and Natural Resources Policy v Union of India, 13 SCC 186 (SC 2005). In the same case, the Court further emphasized the duty of government and authorities to motivate public participation. See Tirpur Dyeing Factory Owners Association v Noyyal River Ayacutdars Protection Association, Civil Appeal No. 6776 of 2009 (SC 2009); S. Nandakumarv. The Secretary to Government of Tamil Nadu Department of Environment and Forest, w.P. No. 10641 to 10643 of 2009 (Madras HC 2010).

93 Orissa Mining Corporation Ltd. v Ministry of Environment \& Forest \& Ors., W.P.(C) No. 180 of 2011 (SC 2013). See also Stellina JOLLY, 'The Vedanta (Niyamgiri) Case: Promoting Environmental Justice and Sustainable Development' in Carmen GONZALEZ, Sumudu ATTAPATTU and Sara L SECK, (eds) The Cambridge Handbook of Environmental Justice and Sustainable Development (Cambridge University Press 2021) 289-302. ibid. 
of India deliberated extensively on the nature, scope and procedures of public hearings in the EIA process. ${ }^{95}$ The court pointed out that the 2006 EIA notification envisaged two components of public consultation: (a) a public hearing at the site or in its close proximity, district-wise, to be carried out for ascertaining the concerns of local affected persons; and (b) obtaining responses in writing from other concerned persons having a plausible stake in the environmental aspects of the project or activity. ${ }^{96}$ The court noted that though the provisions for public consultation postulated the physical presence of locally affected persons at a public hearing, they are not barred from giving their responses in writing to the authorities involved in the public consultation process, even though they may not have attended the public hearing. ${ }^{97}$ The court stated that a notice of at least 30 days in advance of the date of the public hearing would give adequate time to all concerned persons to offer their comments and suggestions on the proposed project. The court also articulated the purpose of public hearing as a form of participatory justice, giving a voice to the voiceless and a place and occasion for them to express their views about the project. ${ }^{98}$

India's experience with public participation in EIA has not been satisfactory. The prejudiced attempts of project proponents and procedural ambiguities in the actions of authorities have compelled the Indian judiciary to rectify the violations and specify the contours of public consultation in EIA. In Adivasi Majdoor Kisan Ekta Sangthan v. Ministry of Environment and Forests, the NGT invalidated the EC obtained on a faulty public hearing. ${ }^{99}$ In Centre for Social Justice v. Union of India, the Gujarat High Court laid down parameters for conducting an effective public consultation. The court noted that the venue of the public hearing should be as near as possible to the site of the proposed project or affected village, and in any case, it should not be further away from the headquarters of the taluka (an administrative district for taxation purposes, often consisting of several villages) in which the proposed project is planned. It further noted that the public hearing notice is to be published in at least two newspapers widely circulated in the region around the project, one of which shall be in the vernacular language of the locality concerned. ${ }^{100}$ Pertinently, not satisfied with the 3 o days of the statutory notice period, the court observed

\footnotetext{
95 Samarth Trust and Anotherv Union of India, W.P.(C) No. 9317 of 2009 (Delhi HC 2010).

96 ibid para 1o. See Hanuman Laxman Aroskarv Union of India, Civil Appeal No. 12251 of 2018 (SC 2019), para 46.

97 Samarth Trust (n 95) para 14.

98 ibid para 17.

99 Adivasi Majdoor Kisan Ekta Sangthan and Anotherv Ministry of Environment and Forests \& Ors., Appeal No. 3/2011 (NGT 2012).

100 Centre for Social Justice (n 91).
} 
that the period of public notice regarding public hearings should be at least three months. ${ }^{101}$ The Delhi High Court in Utkarsh Mandal $v$ Union of India observed that a public hearing furnishes a decentralized democratic space and that it is pertinent to provide information at least 30 days before this process. ${ }^{102}$ Notably, when public consultation practices and periods of notice already face problems in India, the suggested dilution will curtail even further the democratic right of communities to participate in environmental governance.

Clause 14(1)(c) of the Draft EIA Notification provides other appropriate modes for conducting public consultation. ${ }^{103}$ What constitutes an appropriate mode has not been clarified, nor has the Draft provided any guidelines. There is a widespread apprehension that the term 'appropriate mode' will be utilized to restrict or curb effective public participation. The fear has been strengthened by the recent practice of the Maharashtra Pollution Control Board, which conducted the virtual environmental hearings through the Zoom video app. The process is problematic as it restricts the maximum participation of affected persons ${ }^{104}$ and fundamentally violates the right of rural, low-income, and tribal people to participate, as they might not have access to such modern means of communication. It is often not possible to invite and proceed with all stakeholders on a virtual platform. The online mode can be a supplementary mechanism for a public hearing when exercised diligently. Nevertheless, under no circumstances should it act as a substitute for physical public hearings.

Effective public participation requires a favorable environment that can only be achieved if people are provided adequate time and facilities to understand the process. ${ }^{105}$ As noted above, the Draft EIA Notification has been published only in two languages, English and Hindi, and posted on the official websites of the Ministry. ${ }^{106}$ Notably, despite the 10 day time limit provided by the Delhi

\footnotetext{
101 ibid.

102 Utkarsh Mandal (n 37).

103 Draft EIA Notification (n 1) clause 14(1)(c).

104 Vaibhav GANJAPURE, 'MPсв's Sand Mining Public Hearings on Zoom Challenged' (Times of India, 10 June 2020) <https://timesofindia.indiatimes.com/city/nagpur/mpcbs -sand-mining-public-hearings-on-zoom-challenged/articleshow/76292144.cms >

105 The Delhi High Court noted that adequate notice must be provided for the public hearings that should involve three vital components: adequate time for preparation, adequate publicity for the benefit of all, and availability of all relevant information, see Samarth Trust (n 95). See also Barbara CARROLL, Josh FOTHERGILL, Jo MURPHY and Trevor TURPIN, Environmental Impact Assessment Handbook: A Practical Guide for Planners, Developers and Communities (ICE 2019).

106 The Ministry has uploaded the Draft EIA Notification 2020 on its two official websites, (a) PARIVESH <http://parivesh.nic.in/writereaddata/Draft_EIA_202o.pdf> and (b) Online Submission \& Monitoring of Environmental \& CRZ Clearances <http://environment clearance.nic.in/writereaddata/Draft_EIA_2020.pdf >.
} 
High Court, at the time of writing, it has neither been translated into the scheduled languages nor uploaded to the State Pollution Control Board (АРсв) and other departmental websites for wide publicity. ${ }^{107}$ As noted earlier, EIA in India has been conceived in the form of an executive notification and hence qualifies as subordinate legislation. The Supreme Court has clarified that wide publication of subordinate legislation is a requirement of the principles of natural justice, which are part and parcel of Article $14 \cdot{ }^{108}$ The inaction on the part of the Ministry to publish the EIA notification in the regional languages can be considered as a violation of the fundamental rights of the citizens who do not know English and Hindi and who, as per the 2011 census, constitute $5^{6}$ percent of the population. ${ }^{109}$

In a country where countless languages ${ }^{110}$ and significant illiteracy prevails, diligent efforts should be undertaken so that the law could become accessible to people in the language known to them. In the separate public interest litigation cases filed before Delhi, Karnataka, and Madras High Courts, the courts have directed the government to translate the Draft EIA Notification into all scheduled languages. ${ }^{111}$ However, the Ministry appeal to the Supreme Court against the Delhi High Court order reveals the government's unwillingness to translate the Draft Notification into any other language.

While the Ministry is attempting to evade its duties, it is pertinent to ascertain different avenues for the translation and wide publicity of the Draft EIA Notification simultaneously. The Vedanta case has highlighted the traditional practices and the vital knowledge of environmental management possessed by the tribes and traditional forest dwellers. However, their distinct culture and limited contact with mainstream society present difficulties in obtaining effective access to justice. In this scenario, the Gram Sabha ${ }^{112}$ can play

107 Vikrant Singh Tongad (n 3$)$.

108 Union of India \& Anor v Tulsiram Patel \& Ors., (1985) 3 SCC 398, para 95.

109 Pranav NARSARIA, 'EIA 2020: Public consultation without informing the public?' (Down to Earth, 19 August 2020) <https://www.downtoearth.org.in/blog/environment/ eia-2020-public-consultation-without-informing-the-public--72919>.

110 As per the 2011 Census in India, 121 languages and 270 identifiable mother tongues are spoken in the country. See Census of India 2011, Language: India, States and Union Territories (Table C-16) <https://censusindia.gov.in/2011Census/C-16_25062018_NEW.pdf> .

111 Vikrant Singh Tongad ( $\left.\mathrm{n}_{3}\right)$; United Conservation Movement (n 6); and Meenava Thanthaiv Union of India, W.P. No. 10391 of 2020 (Madras HC 2020).

112 Article 243 (b) of the Indian Constitution defines it as, 'In this Part unless the context otherwise requires - "Gram Sabha" means a body consisting of persons registered in the electoral rolls relating to a village comprised within the area of Panchayat at the village level'. The Gram Sabha is empowered to exercise regulatory powers and perform functions under Panchayats (Extension to the Scheduled Areas) Act, 1996 and Scheduled Tribes and Other Traditional Forest Dwellers (Recognition of Forests Rights) Act, 2006 to maintain the sustainability of the village and its resources. 
an active role in not only safeguarding the customary and religious rights of individuals and communities ${ }^{113}$ but can be suitably entrusted with the task of wide publicity of the Draft EIA Notification among the communities. In the light of the dilution of public consultation in EIA, it is crucial to strengthen the Gram Sabha and involve them in circulating the Draft EIA Notification in the vernacular language and other related functions. The АРсв should initiate the Draft EIA Notification translation into their primary state languages and further assist Gram Sabha in strategizing their course of action. The Gram Sabha can take up the task of explaining and discussing the provisions of the Draft EIA Notification with local people to make them understand the inherent technical provisions. ${ }^{114}$ This village-level self-governing institution may further aid and facilitate the local or tribal population to submit their suggestions or comments to the Ministry. The Gram Sabha is a constitutional body that can effectively secure environmental democracy in the country. It can play a vital role in strengthening public participation in the environmental decisionmaking process as enshrined in Principle 10 of the Rio Declaration.

\subsection{Projects with Transboundary Impact}

The Draft EIA Notification is silent on the transboundary impact of projects and the process to be followed. It defines 'Border Area' as the area falling within 100 kilometers aerial distance from the Line of Actual Control with bordering countries of India ${ }^{115}$ and exempts some projects in the border areas from public consultation. ${ }^{116}$ It is problematic that the highways or pipeline projects carried out in this area will be exempted from the public consultation process. ${ }^{117}$ This provision will gravely impact several parts of India. For instance, the Northeastern States is an ecologically sensitive region and a biodiversity hotspot. ${ }^{118}$ These border projects are also likely to generate transboundary

\footnotetext{
113 Vedanta (n 93).

114 ibid para 39 and 40.

115 Draft EIA Notification (n 1 ) clause $3(6)$.

116 ibid clause $14(2)$.

117 ibid item 31 and 38 of the schedule.
}

118 All the eight North-Eastern States of India, comprising of Arunachal Pradesh, Assam, Manipur, Meghalaya, Mizoram, Nagaland, Sikkim, and Tripura, shares an international border with the neighboring states. They are home to 16 national parks, $5^{8}$ wildlife sanctuaries, 3 Ramsar sites, and parts of the Indo-Burma biodiversity hotspot. A government report presented at the Katowice climate summit mentioned this region to be highly vulnerable to climate change's adverse effects due to the low adaptive potential of its demography. See Sayan BANARJEE, 'Draft EIA 2020: How it May Impact North East' (Down To Earth, 10 August 2020) <https://www.downtoearth.org.in/blog/environ ment/draft-eia-202O-how-it-may-impact-north-east-72742>; Abhishek SAHA, 'Former 
impacts. The exclusion of public consultation in the border projects needs to be evaluated in the broader context of international law. The commentary to Article 7 of the International Law Commission Draft Articles on Prevention of Transboundary harm 2001 (ILC Draft), which deals with the requirement to conduct an EIA, refers explicitly to the proximity of a project to border areas to indicate the transboundary nature of a project and the trigger for an EIA. ${ }^{119}$ Further, Article 13 of the ILC Draft obliges States to provide relevant information relating to the risk of harm resulting from activity to all people likely to be affected by it and to ascertain their views. ${ }^{120}$ The commentary to the instant Article states that public participation could be viewed as a growing right under national and international law, given the development of human rights jurisprudence. ${ }^{121}$ International law advances further support it. Public participation in the screening, scoping, and at different stages of environmental assessment forms part of the process under the Espoo Convention, ${ }^{122}$ and 1998 unece Aarhus Convention on Access to Information, Public Participation in Decision-Making and Access to Justice in Environmental Matters. ${ }^{123}$ Thus, public consultation constitutes a significant EIA element in the transboundary context and cannot be restricted except for legally justified reasons.

The ICJ has strengthened the prevention of transboundary harm principle, the precautionary principle, and the need to conduct an environmental impact assessment to prevent transboundary harm in several judgments. ${ }^{124}$ The principle of prevention of transboundary harm constitutes the foundation of international environmental law and is declared as a customary international law. ${ }^{125}$ It obliges states not to cause serious harm to the environment of

Assam CM Gogoi writes to PM Modi, urges him to withdraw draft EIA notification' (The Indian Express, 31 July 2020) <https://indianexpress.com/article/north-east-india/ assam/former-assam-cm-gogoi-writes-to-pm-modi-urges-him-to-withdraw-draft-eia -notification-6532090/>.

119 International Law Commission, Report of the Commission to the General Assembly on the work of its fifty-third session, Prevention of Transboundary Harm from Hazardous Activities with commentaries (23 April-1 June and 2 July-10 August 2001) 2 Yearbook of International Law Commission Part Two A/CN.4/SER.A/20o1/Add.1(Part 2) 148, article 7, 159, para 9 <https://legal.un.org/ilc/publications/yearbooks/english/ilc_2001_v2_p2.pdf>.

120 ibid art $13,165$.

121 ibid art 13, 166, para 10.

122 Espoo Convention ( $\mathrm{n} 78)$.

123 Aarhus Convention (n 78$)$.

124 Corfu Channel case (United Kingdom v Albania), Merits Judgment, 1949 ICJ 4, 22 (9 April 1949); Pulp Mills (n 70); Costa Rica v Nicaragua (n 67).

125 ibid; see Trail Smelter Arbitration (United States v Canada), Arbitration Tribunal, 19413 U.N. Rep. International Arbitral Awards 1905-1982, 1965; Lake Lanoux Arbitration (France 
other states or the areas beyond national jurisdiction. ${ }^{126}$ The ICJ has clarified that the obligation is one of prevention founded on due diligence. ${ }^{127}$ In the Pulp Mills case, it acknowledged EIA to be a necessary element of the due diligence obligation and recognized the need to conduct a prior transboundary impact assessment in projects likely to cause significant transboundary harm, as a requirement of general international law. ${ }^{128}$ In the Pulp Mills case, while the court did not find a legal obligation to consult the affected public, it did find that Uruguay consulted with affected populations of both nations. ${ }^{129}$ The fact that the ICJ referred to Uruguay's consultation of the affected population in a positive tone indicates the significance of the de facto public consultation undertaken in the actual EIA process. Scholars have vehemently criticized the court's omission for categorizing public consultation as a legal obligation in transboundary projects as a flawed understanding of international law, referring to the fact that most of the conventions dealing with international environmental laws incorporate public consultation as an essential requirement of EIA. ${ }^{130}$

The Draft EIA Notification provision exempting public consultation in border areas may be intended to exclude the possibility of public consultation in transboundary contexts. It may be argued that such a provision does not exist under the domestic laws. However, it deprives communities of the opportunity for public participation and goes against the spirit of domestic

$v$ Spain) (1957) 12 R.I.A.A. 281; Legality of the Threat or Use of Nuclear Weapons, Advisory Opinion, 1996 I.C.J. Rep., 226, 241-42.

126 Akiko TAKANO, 'Due Diligence Obligations and Transboundary Environmental Harm: Cyber Security Applications' (2018) 7(4) Laws 36.

127 Marte JERVAN, 'The Prohibition of Transboundary Environmental Harm. An Analysis of the Contribution of the International Court of Justice to the Development of the No-Harm Rule' (2014) Pluri Courts Research Paper No. 14-17.

128 Pulp Mills (n 70) para 204. See Costa Rica v Nicaragua (n 65) para 104; Alan BOYLE, 'Developments in the International law of EIA and their Relation to the Espoo Convention' (2011) 2O Review European Community and International Law 227; Alan BOYLE, 'Pulp Mills Case: A Commentary' (2010), <https://www.biicl.org/files/5167_pulp_mills_case. pdf>; Tseming YANG, 'The Emergence of the Environmental Impact Assessment Duty as a Global Legal Norm and General Principle of Law' (2019) 70(2) Hastings Law Journal 525 .

129 Pulp Mills (n 70) para 216-219.

130 ibid; Edouard FROMAGEAU, 'Sustainable Development, Environmental Impact Assessments and the Obligation to Consult: Pulp Mills on the River Uruguay' in Sabino CASSESE, Bruno CAROTTI, Lorenzo CASINI, Eleonora CAVALIERI and Euan MACDONALD (eds). Global Administrative Law: The Casebook (3rd ed IRPA-IILJ 2012) 74-83. Cymie R PAYNE, 'Environmental Impact Assessment as a Duty under International Law: The International Court of Justice Judgment on Pulp Mills on the River Uruguay' (2010) 14(9) European Journal of Risk Regulation 317; Espoo Convention (n 78) art 7; UN Environment Goals and Principles of Environmental Impact Assessment 1987. 
and international law. It may also have negative repercussions for India at the international level. For example, the absence of a provision on public consultation in projects involving transboundary impact in Indian domestic law may make it difficult for India to request that such consultation be conducted by neighbouring States. For example, in the Indus Water Kishenganga Arbitration case, Pakistan had alleged that the EIA conducted by India had not adopted best practice. The Permanent Court of Arbitration observed that 'the environmental sensitivity that Pakistan urges in these proceedings does not match Pakistan's own historical practices.' ${ }^{131}$ Pakistan was, therefore, prevented from seeking a standard in EIA practice that it did not set for itself domestically.

It is clear that the absence of public consultation in border projects might provoke bordering countries to initiate projects in their border areas without regard to the voices of the affected public. This is potentially detrimental to the environment and people residing in those border areas. International environmental law is based upon cooperation between States. This obligation necessitates States to incorporate sound EIA processes in one's domestic laws with due regard to public consultation to the projects having transboundary impacts. The EIA process not only identifies the adverse effects on the environment but also aims to analyze the impacts on social and cultural components. ${ }^{132}$ To this effect, public participation plays a crucial role in integrating the project's socio-economic impacts with environmental concerns. ${ }^{133}$ It is, therefore, essential for any State committed to achieving sustainable development that the fair practices equipped with the core environmental principles should be employed while conducting an EIA.

\section{5 Conclusion}

This article has sought to examine the salient legal architecture of the Draft EIA Notification issued by the Ministry on 23 March 2020 and that has resulted in national outcry. It has been shown that many of its provisions represent a dilution of an already problematic EIA system in India, a system plagued by accountability gaps, a lack of transparency in the environmental clearance process and poor quality opportunities for public participation.

\footnotetext{
131 Indus Water Kishenganga Arbitration (Pakistan v India), Final Award, 2013 P.C.A. 1, 36, para 101 (20 December).

132 Philippe SANDS, Jacqueline PEEL, Adriana FABRA and Ruth MACKENZIE, Principles of International Environmental Law (4th ed Cambridge University Press 2018) Ch 14, 'Environmental Impact Assessment'.

133 ibid, 657 .
} 
Three problematic areas were identified: ex post facto clearance, reduced space for public consultation, and the exemption from public consultation granted to transboundary projects. The Draft EIA Notification attempts to institutionalize the ex post facto clearance go against the basic premises of EIA and would deprive the opportunity for incorporating suitable and adequate safeguards, creating the prospect for irreparable environmental and social damage. These types of consequences were witnessed in the recent ecological catastrophe in the Visakhapatnam styrene gas leak case where the entity was operating without necessary environmental clearance for years. The ex post facto clearance mechanisms also work against the precautionary principle incorporated as part of the Indian domestic legal framework and international law. The Draft EIA Notification has not only exempted a long list of projects, ranging from building, construction, and offshore gas to modernization of irrigations projects from public consultation, but it has also reduced the period of public hearing from 30 to 20 days. When periods of consultation have been subject to judicial decisions in India, the judiciary has repeatedly highlighted the need for adequate time for public consultation. In the light of the socio-economic circumstances and geographical locations of the vulnerable populations affected by the projects, restricting the consultation period to 20 days cannot be considered reasonable and would practically exclude many groups from the consultation. There is also the concern that the Draft EIA Notification has only been published in English and Hindi. Inaction on the part of the Ministry to publish it in the regional languages is a violation of the fundamental rights of the citizens who do not know English and Hindi and who, as noted, constitute $5^{6}$ percent of the population. The Draft EIA Notification's exemption of public consultation in projects near the border areas may result in significant environmental consequences and sits counter to international legal developments concerning public consultation in transboundary EIA. The Draft EIA Notification in the current form is regressive and needs to be reformed and strengthened to address the significant potential for environmental catastrophe and harm to local communities and wider society.

\section{Acknowledgements}

The authors wholeheartedly thank the peer reviewers, and the CJEL editors for their valuable comments on an earlier draft of this article. 